\title{
Beskytter imatinib fertiliteten under kjemoterapi?
}

\author{
Fertiliteten påvirkes negativt av celle- \\ gift som cisplatin. Nye forsknings- \\ resultater tyder på at imatinib kan \\ beskytte ovariene mot denne bivirk- \\ ningen.
}

Infertilitet er en alvorlig bivirkning av cellegift hos unge kreftpasienter. Mens unge mannlige pasienter har hatt mulighet for sædbanking forut for terapi, har unge kvinnelige kreftpasienter færre tilsvarende muligheter til å sikre svangerskap etterpå. En italiensk forskningsgruppe har nå vist at imatinib kan preservere fertiliteten hos mus behandlet med cisplatin (1).

Forskerne gjorde cellestudier som viste at germinalcellene blir eliminert via p63reaksjonsveien under cellegiftbehandling. Denne effekten kunne reverseres ved å hemme tyrosinkinasen c-Abl med imatinib i musemodeller. Mus som fikk både cisplatin og imatinib fikk like mange musebarn som ubehandlede mus. Dette i motsetning til mus som kun fikk cisplatin.
- Dette er en svært spennende studie som viser at imatinib beskytter museoocytter mot de skadelige effektene av kjemoterapi, sier stipendiat Cecilie E. Kiserud ved Nasjonalt kompetansesenter for langtidseffekter etter kreftbehandling ved Oslo universitetssykehus, Radiumhospitalet.

- Det gjenstår imidlertid mer forskning, både på dyr og mennesker før dette eventuelt kan tas i klinisk bruk. Man vet for eksempel lite om oocyttene er helt beskyttet fra cisplatins virkninger, eller om de påføres noe skade under cellegiftbehandlingen. Hvorvidt imatinib også påvirker effekten av cellegiftbehandlingen på tumorcellene må undersøkes grundig, slik at adekvat kreftbehandling er sikret, sier Kiserud.

Åslaug Helland
aslaug.helland@gmail.com
Tidsskriftet
Litteratur
1. Gonfloni S, Di Tella L, Caldarola S et al. Inhibition
of the c-Abl-Tap63 pathway protects mouse oocy-
tes from chemotherapy-induced death. Nat Med
2009; 15: 1179-85.

\section{Åslaug Helland}

aslaug.helland@gmail.com

Litteratur

\section{Gen som disponerer for stressreaksjon}

Genet som koder for serotonintransportøren i hjernen har betydning for psykologiske reaksjonsmønstre. Tidligere studier har vist at lengden av promotordelen av genet (polymorfismen) bestemmer genreguleringen, og at personer med korte alleler har økt risiko for å utvikle depresjon hvis de utsettes for belastende livshendelser. Resultater fra en ny studie viser at det sannsynligvis finnes en slik sammenheng for utvikling av posttraumatisk stresslidelse (PTSD) (Arch Gen Psychiatry 2009; 66: 1201-9). Blant nesten 1100 personer som hadde opplevd traumatiske hendelser i barndom eller voksen alder, var sannsynligheten for posttraumatisk stresslidelse omkring dobbelt så høy for dem som var homozygote for det korte allelet.

\section{Slanking kan føre til overspising \\ Mange slankekurer innebærer fravær av smakfull mat for å unngå høyt matinntak. En amerikansk forskergruppe har simulert dette i rottestudier og tatt bort smakfull mat i perioder (Proc Natl Acad Sci USA 2009; 106: 20016-20). Rottene overspiste når de fikk tilgang på smakfull mat, og i periodene uten dette, ble de tilbaketrukne og hadde angstliknende symptomer. \\ Den sosiale tilbaketrekningen var fulgt av en økning i kortikotropinfrigjørende fak- tor, og en økning i aktiviteten til dennes reseptor i amygdala. Dette er et system som tidligere har vært implisert i utviklin- gen av narkomani. \\ Forskergruppen tolker dette som at fra- vær av god og smakfull mat i en periode kan medføre overspising av slik mat når til- gangen gjenopprettes, og at dette er ana- logt til abstinens ved stoffavhengighet.}

\section{Kjønnshormonbindende globulin og type 2-diabetes}

Nye funn viser en mulig årsakssammenheng mellom nivå av kjønnshormonbindende globulin og diabetes.

Transportøren av kjønnshormoner, kjønnshormonbindende globulin (SHGB), binder og transporterer østrogener og androgener i plasma. Resultater fra tidligere studier har vist en sammenheng mellom SHGB-nivå og insulinresistens, men man har ikke visst om det er noen sikker sammenheng mellom SHGB-nivå og risiko for diabetes.

I en nestet pasient-kontroll-undersøkelse har man nå undersøkt plasma fra 359 kvinner med nyutviklet type 2-diabetes og like mange kontrollpersoner (1). Resulta- tene viste en sikker sammenheng mellom lave SHBG-nivåer og utvikling av diabetes over ti år. I multivariate analyser var oddsratio $0,1 \mathrm{i}$ den høyeste versus den laveste SHBG-kvartilen. I tillegg undersøkte man serum fra deltakere i en annen helseundersøkelse og fant at sammenhengen mellom SHBG-nivå og diabetes var omtrent den samme for menn som for kvinner.

- Dette er et viktig funn, sier seksjonsoverlege Tore Julsrud Berg ved Endokrinologisk avdeling, Oslo universitetssykehus, Aker. - Man har tidligere trodd at lave SHBG-nivåer skyldes insulinresistens. Resultatene fra studien viser at SHBG er en selvstendig risikofaktor, uavhengig av de tradisjonelle som for eksempel insulinresis- tens, overvekt, lite fysisk aktivitet, røyking, hypertensjon og diabetes i familien. Det imponerende er at de også viser at enkelte polymorfismer i $S H B G$-genet predikerer diabetesutvikling via SHBG-nivået. Dette viser en mulig årsakssammenheng mellom SHBG-nivå og diabetes, sier Berg.

\footnotetext{
Ragnhild Ørstavik

ragnhild.orstavik@fhi.no

Tidsskriftet
Litteratur
1. Ling $E$, Song $Y$ Manson JA et al Sex hormone- binding globulin and risk of type 2 diabetes in women and men. N Engl J Med 2009; 361: $1152-63$
} 